Scientific journal

PHYSICAL AND MATHEMATICAL EDUCATION

Has been issued since 2013 .

Науковий журнал

ФІЗИКО-МАТЕМАТИЧНА ОСВІТА

Видається з 2013.
IS S N 2413-158X (online)

ISS N 2413-1571 (print)

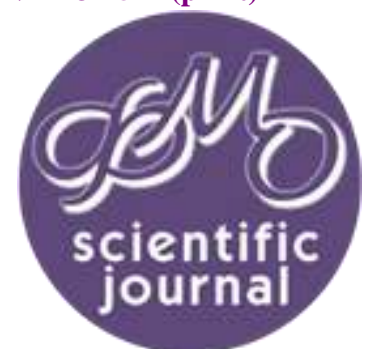

Слободянюк І.Ю., Мисліцька Н.А., Заболотний В.Ф., Колесникова О.А. використання хмаро орієнтованих технологій в умовах дистанційного навчання. Фізико-математична освіта. 2020. Випуск 1(23). Частина 2. С. 78-82.

Slobodianiuk I., Myslitska N., Zabolotnyi V., Kolesnykova O. Use of cloud-oriented technologies in the condition of distance education. Physical and Mathematical Education. 2020. Issue 1(23). Part 2. P. 78-82.

\title{
DOI 10.31110/2413-1571-2020-023-1-2-012
}

УДК 004.77:37

І.Ю. Слободянюк

Барський гуманітарно-педагогічний коледж імені Михайла Грушевського, Україна islobodianuk@gmail.com

ORCID: 0000-0002-1249-8729

Н.А. Мисліцька

Вінницький державний педагогічний університет імені Михайла Кочюбинського, Україна mislitskay@gmail.com

ORCID: 0000-0002-1806-4737

В.Ф. Заболотний

Вінницький державний педагогічний університет імені Михайла Коцюбинського, Україна

Zabvlad@gmail.com

ORCID: 0000-0002-7866-6000

О.А. Колесникова

Вінницький державний педагогічний університет імені Михайла Коцюбинського, Україна

oxy_10@ukr.net

ORCID: 0000-0002-1302-7339

ВИКОРИСТАННЯ ХМАРО ОРІЄНТОВАНИХ ТЕХНОЛОГІЙ В УМОВАХ ДИСТАНЦІЙНОГО НАВЧАННЯ

\section{АНОТАЦІЯ}

Формулювання проблеми. Реалії сучасності, з якими зустрілася світова чивілізація у зв'язку з пандемією, особливо гостро позначиласявосвітянській галузі. За досить короткий інтервал часувикладачі іучителі вимушені буликардинально змінити форми, засоби, методи, прийоми і способи навчання. I саме хмарні сервіси стали вагомою технічною підтримкою всистемі організаціїдистанційного навчанняучнів та студентів. Однак, серед різноманіттянаявнихна сьогодні, необхідно відібрати ті, які є ефективними та найбільш адаптованими до но вого формату навчання.

матеріали і методи. Уході дослідження було використано такі основні теоретичні методи: аналіз, систематизація та узагальненнянавчально-методичнихматеріалівінауковихпрацьз проблеми дослідження, педагогічніспостеренення за освітнім процесом в умовах дистанційної форми навчання та апробація запропонованих хмарних сервісів.

Результати. Використанняхмарнихсервісів LearningApps, StudyStack, EDpuzzle, Kahoot, Quizizzвумовахдистанційногонавчання учнівта студентівсприяєурізноманітненнюметодівта прийоміворганізаціїпоясненнянавчальногоматеріалу, актуалізачії та закріплення вивченого матеріалу, перевірки навчальних досягнень.

Висновки. Проведено аналіз актуальнихдослідженьщодо впровадження технологіїдистанційного навчання, який засвідчив, що дослідникинадаютьперевагуасинхронномурежимудистанційноїосвіти. Описано дидактичніможлиостіхмарних сервісів LearningApps, StudyStack, EDpuzzle, Kahoot, Quizizz, які були апробовані під час організації дистанційного навчання з фізики. Здійснено порівняння технічних та дидактичних можливостей зазначених хмарних сервісів. Виокремлено методичні поради щодо ерективної організації освітнього прочесу в умовахдистанційного навчання.

КЛЮчОВІСЛОВА: дистанційненавчання, хмаро орієнтовані технології, хмарнісервіси, LearningApps, StudyStack, EDpuचle, Kahoot, Quizizz.

ВСТУП

Постановка проблеми. 2019-2020 на вча льний рі к ста в особливим не лише для України, а ле й для ба гатьохкраїн світу, оскільки через запровадження карантинних заходів, освітній процес зазнав трансформації та проходить за дистанційною формою. Однак, освітня галузь була не готовою до такого сценарію. Перед закладамиосвітипосталобагато нових за вдань, які потребува ли на гального вирішення. Ча стина за кладів запровадила перехі д на дистанці йну форму на вча ння з використа нням спеці а лі зова них платформ (GoogleClass, Class time, Moodle тощо), інші-звикористаннямгруп 
у соці а льних мережах та месенджерах; і самостійно, методом спробта помилок, вибудовува ли свою тра єкторіюрухуза заданим сьогоденням вектором.

На сьогодні не існує уні версальної освітньої платформи, яка б враховувала специфі ку навчаннякожногопредмету і, з точки зору методики, задовольняла всіх педагогів. Та і чи можливо подібну створити? У таких випадках варто використовувати наявні сьогодні хмарні сервіси та додатки, за допомогою яких можна реалізовувати конкретне педагогічне завдання чи ідею.

Аналіз актуальних досліджень. Серед наукових пра ць та публі ка цій ві дносно реалізації дистанційногонавчанняв осві тньому процесі, слід ві дзначити дисерта ці ю М.О. Моклюка, в якій автором за пропонова ноітеоретинообгрунтовано використання елементів дистанційних технологій під час навчання фізики в закладах середньої освіти, практичне впрова дження якої зреа лізова но в на вча льно -методичному компле ксі для вивчення розді лу “Квантова фізика”,якийбуло апробовано на базі Вінницького міського центру дистанційної освіти (Моклюк, 2009).

Досить детально описано дистанційне навчання в груповій моногра фії (Кухаренко \& ін., 2016), зокрема, углаві «Система диста нційного на вча ння» на веде но визначення систе ми диста нці йного на вча ння та її складових:інформаційної, організаційної, методичної, програмної і технічної підсистем. Враховуючи велику роль дистанційного на вчання при організації змішаного навчання, у главі «Дистанційний на вча льний процес» розглянуто питання структури і вимог до дистанційного курсута тьютора; докладно описано модель та функції тьютора; надано хара ктеристикудистанційного студента та можливі труднощі, які виникатимуть, особливо на першому тижні дистанційних занять.

Використанню елементів дистанційних технологій присвячено публікації В.Л. Бузько, С.П. Величка, В.Ф. Заболотного, М.В. Головка (Головко, Крижановський \& Мацюк, 2015), І.В. Коробової, О.В. Мерзлікіна, В.В. Чернявського, М.І. Шута. Їхана ліз за сві дчив, що дослі дники нада ють пе рева гу а синхронному режимудиста нційної освіти.

Реалії суча сності, з якими зустрі лася світова циві лізація узв'язку з пандемією, особливо гостро позначилася в осві тянській га лузі. За досить короткий інтервал часувикладачі і учителі вимушені були кардина льно змінити форми, засоби, методи, прийоми і способи навчання. Чи готова була до цього спільнота освітян України? Звичайно, ні. І це зрозумі ло, адже освітяни повинні були в інтенсивномутемпі освоїти новий вид ді яльності, до якого долучити студентівта учнів, який теоретично фра гментарно дослі джува вся, а впрова дження пра ктикува ла сь швидше якзмішане навчання.Так, наприклад в окремих за кладах вищої осві ти працює система Moodle, одна к робота в цій системі передбачаєорганізацію самостійної діяльності студенті в в а синхронному режимі. УВінниці вже ба гато рок ів працюєцентр дистанційноїосвітина базі фізико-математичної гімна зії №17, де та кож передбачено а синхронний режим дистанційного навча ння усистемі змі шаного. Як виявилось, реа льного грунтовного дослі дження і а проба ції диста нці йного на вчання увітчизняні йсистемі освітине було. Водночас, ще у 2013 році МОН України було розроблено та оприлюднено «Положення про дистанційне на вча ння» (МОН України, 2013), яке ча стково було доповнено у 2015 році. Впродовжчотирьох років жоднихзміндоцього положення не внесено, в той час як засоби і технології змінюються не просто у швидкому темпі, а у надзвичайно швидкому. Як свідчить огляд навчальних планів, зокрема у Вінницькому державному педагогічному університеті імені М. Коцюбинського, не передбачалось ґрунтовного ознайомлення та пра ктичного відпрацювання цієї технології майбутніми учителями. Не зверталась увага на цей вид технологій і на курсах підвищення кваліфіка ції учителів і викладачів. Саме ці причини і є поясненням неготовності до такого видудіяльності сучасних педагогів і виникнення труднощів та недоліків під час реалізації дистанційного навчання. І саме хмарні сервіси стали вагомою технічною підтримкою в системі організації дистанційного навчання учнів та студентів.

Метою cmammi є опис основних дидактичних можливостей апробованих авторами хмарних сервісів, їх порівняння щодо адаптованості до використання в умовах дистанційного навчання.

\section{МЕТОДИ ДОСЛІДЖЕННЯ}

Для досягнення поставленої мети було використано та кі теоретичні методи дослідження: а на ліз, системативація та узагальнення навчально-методичних матеріалів та наукових праць з проблеми дослідження, педагогічні спостереження за освітнім процесом в умовах дистанційного навчання та апробація запропонованих хма рних серві сів.

\section{РЕЗУЛЬТАТИ ДОСЛІДЖЕННЯ}

Серед існуючого сьогодні арсена лу Інтернет-дода тків, хма рних серві сів та web-iнструментів кожен сучаснийта креативний педа гог може обиратиті, які, на його думку, задовольнятимуть освітнім потребамумежахйого предмету. Проаналізуємо окремі сервіси та додатки з позиції доцільності їх використання на різних етапах уроку в умовах дистанційної форми навчання, зокрема LearningApps, StudyStack, EDpuzzle, Ka hoot та Quizizz.

Традиційно заняття розпочинається з актуалізації опорних знань. В умовах дистанційного навчання зручно використовувати online сервіси LearningApps та StudyStack. LearningApps надає можливість розробляти інтера ктивні впра ви на основі на явних ша блоні в (За болотний, Слободянюк \& Мисліцька, 2018). Їх ва рі а тивні сть даєможливістьщоразу змінювати тип завдання, урізноманітнюючи процес навчання. Сервіс передбачає можливість створення класів та реєстра ці ю здобувачів освіти. У розді лі ста тистика вчите лю ві добра жат иметься чи викона в учень/студент за вда ння,а також затрачений на це час (рис. 1 а). Оскільки функція виставлення балів відсутня у всіх завданнях, окрім вправи «Вікторина», використовувати сервіс із метою проведення оцінювання неможливо.

Web-додаток StudyStack дає можливість розробляти засоби для організації повторення, закріплення та самопере ві рки зна нь. Сформува вши вла сний блок за пита нь-відпові дей з певної теми, вчитель може змінюва ти спосібїх подання: увигляді флеш-карти, ві дпові дності, кросворду, ві кторини тощо. Він не передбачає реєстраціїта автентифікації особи, а томутежне може використовуватися для контролю рівня засвоєння знань, з пода льшим виставленням оцінки. Однак, серед запропонова них до використання типі в за вдань $€$ Quiz та Test, які пі сля їх викона ння, передбачаютьфункцію автоматичної перевірки (рис. 1 б). Вона може слугувати індикатором для здобувача освіти рівня засвоєння ним навчального матеріалу (здійснення самооцінювання). 


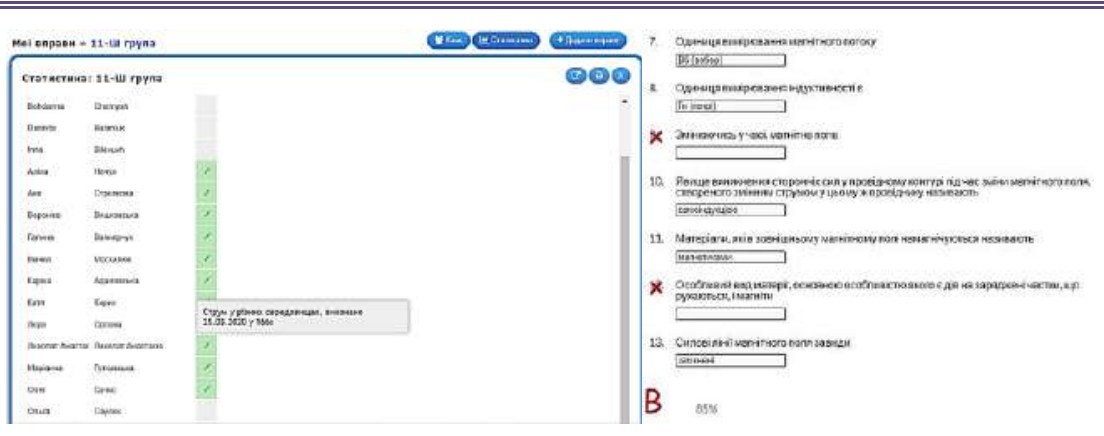

Рис. 1. Скріншот вікна статистики в LearningApps (а) та фрагменту завдання Test y StudyStack

Найбільшої трансформації зазнав процес пояснення навчального матеріалу. Частина педагогів практикує са мостійне опра цювання учнями/студента ми парагра фів підручників та ма теріалів лекцій, окремі -додаютьпосилання на доповнюючі пояснення відеоматеріали. Очевидно, що це не приносить бажаного результату. Ефективнимвиходоміз ситуації є проведення online-уроку, використовуючи суча сні сервіси, зокрема Zoom, Google hangouts,Skype,Discord тощо. Однак, не всі уча сники осві тнього процесу ма ють пості йний доступ до які сного Iнтернету. В та комувипадкуальтернативою може бути запис ві деопояснення педа гогом, перегляда ти який можна в зручний для кожного учня/студента час.Відомо, що успі шність на вча льного проце су за лежить і від особливосте й вза ємодії мі ж учите лем та учнем. Одним ізінструментів інтера ктивної взаємодії уча сників осві тнього процесу, що за безпечує зворотній зв'язок уході пояснення на вчального ма тері а лу, єI нтернет-се рві ED puzzl е. Змонтува вши не обхі дний ві деома тері ал, вчитель має можливістьдодатидо нього за питання, тестове за вда ння, на які учень/студент має обов'язково ві дповісти на да ному ета пі, а бо коментар (рис.2).Для перегляду учень/студент повинен авторизуватися, оскільки сервіс забезпечує відображення дося гнень кожного. В подальшому, аналізуючи надіслані відповіді, учитель має можливість оцінити рівень усвідомлення та засвоєння на вча льного ма тері алу. За потреби, відповідь на за пита ння можна уточнити а бо скоригува ти у коментарях. Така форма роботи сприяє більш якісному вивченню навчального матеріалу та підвищенню пізнавального інтересу.

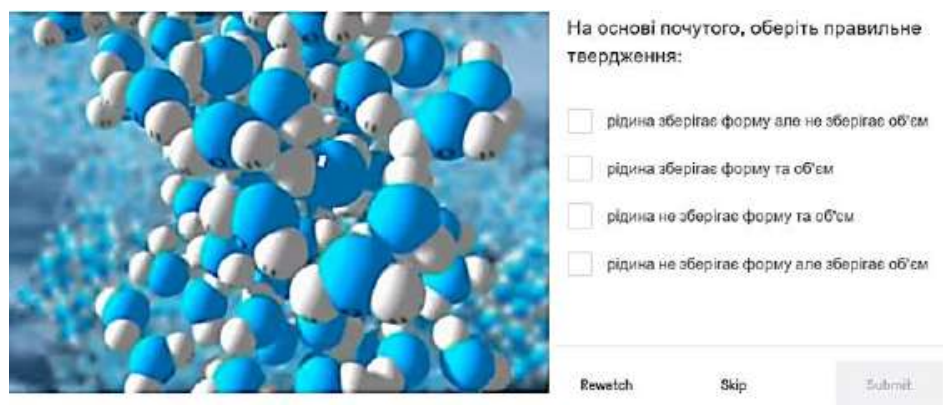

Рис. 2. Фрагмент завдання у сервісі EDpuzzle

Невід'ємних етапом освітнього процесу, в томучислі і за дистанційної форми, єперевірка та оці нюваннянабугх знань. Серед методів їх проведення виокремлюють усні (фронтальне та індивідуальне опитування) та письмові (найпоширеніші - самості йні та контрольні роботи, в томучислі тестового типу, твори, диктанти, письмові залікитощо). Безумовно, вчитель може подати перелі к запита нь, на які не обхідно дати письмовувідповідь. Однак,така форма роботи не принесе задоволення а ні здобувачеві освіти, а ні самому педа гогу, оскі льки передбачатиме додаткові часові затрати як на написання відповідей, так і на їх перевірку. На сьогодні арсе нал кла сичних засобів для проведення оці нювання здобувачів освіти потрібно доповнити Інтернет-інструментарієм. Серед та ких серві сів, найбі льш вдалими, з нашого погляду, є Ka hoot та Qui zizz. Оці нювання з їх використа нням, зводить до мі ні муму можливі сть користуватисядодатковими джерелами інформації пі д ча с тестування. А тому, да єможливість побачити бі льш реа льну картину щодорівнязасвоєня на вча льного матеріа лу. Якщо тестува ння передбачає питання з одиничним вибором ві дпові ді або завданнятипу«так-ні», можна використовувати сервіс Ka hoot. Дані типи за вдань єбезкоштовними, одна к решта - передбачає використання платної pre mium-версії. Бі льш уні ве рса льним за собом для пере ві рки рі вня зна нь здобувачі в осві ти $€$ се рвісQиizizz.Becь його функціонал є безкоштовним. Для створення завдань передбачено 5 варіантів:

- тест відкритого типу, який передбачає необхідність записати у поле числову а бо текстову відповідь;

- тест з вибором однієї правильної відповіді;

- тест з кількома правильними відповідями;

- опитування з готовими варіантами відповідей;

- опитування, що передбачає свій варіант відповіді.

Сервіс Quizizz надає можливі сть створення кла сів, а та кожїх імпорт з пла тформи Googledass (БогачковЮ.М.,Букач А.В. \& Ухань П.С., 2020).

Що стосується обов'язкових письмових робіт, в томучислі і розв'язування задач, досить зручним є використання Google-форм. Наприклад, вчитель увідведеному блоці формулюєзавдання, яке учень пі сля викона ння прикріплюєдо форми. У на лаштува ннях передбачена можливі сть оці нювання кожного за вда ння та автома тичне сумува ння на бра них балів за за повнення всі єї форми. Як зазначено у роботі (Куча ковська Г.А., Бодненко Д.М. \& Прошкін В.В.,2019),перевагою використа ння Google -форм єможливість здійснення статистичного а налізу результаті в, які ві добража ються увигляді таблиці, що містить всі відповіді студентів. 


\section{ОБГОВОРЕННЯ}

Усі описані сервіси є сумісними з різноманітними технічними пристроями та підтримуються операційними системамиWindows, iOS, Android. Але кожен з них має свої функці ональні особливості, які представлено в таблиці.

Порівняння технічних та дидактичних можливостей хмарних сервісів

Табличя 1

\begin{tabular}{|c|c|c|c|c|}
\hline $\begin{array}{c}\text { Назва } \\
\text { сервісу/додатку }\end{array}$ & $\begin{array}{c}\text { Авторизований } \\
\text { доступ }\end{array}$ & $\begin{array}{c}\text { Сумісність з мобільними } \\
\text { пристроями }\end{array}$ & $\begin{array}{c}\text { Функція } \\
\text { оцінювання }\end{array}$ & $\begin{array}{c}\text { Встановлення часу доступу, } \\
\text { тривалості виконання } \\
\text { завдань }\end{array}$ \\
\hline LearningApps & + & + & - & - \\
\hline StudyStack & - & + & - & - \\
\hline EDpuzzle & + & + & + & - \\
\hline Kahoot & + & + & + & + \\
\hline Quizizz & + & + & + & + \\
\hline Google-форма & + & + & + & - \\
\hline
\end{tabular}

Серед описаних хмарних сервісів та додатків лише LearningApps має україномовний інтерфейс, решта англомовні. Безумовно, це може стати перепоною в освоєнні основ роботи з нимита їх впровадженню в освітнійпроцес. Тому, нами розроблено навчально-методичний посібник "Хмаро орієнтовані технології навчання» (Заболотний, Мисліцька \& Слободянюк, 2020), якиймістить детальні інструкції стосовно організації роботи з такими сервісамита розробки дидактичних за собів на їх основі.

І з вла сного досві дупра ктичної реа ліза ції диста нці йного на вча ння (оскі льки МОН України лише всередині травня опублі кува в рекоменда ції щодо органі за ції диста нці йного на вча ння в школі (Коберник \& Звиняцьківська, 2020),хоча на окремих освітянських порталах наводилися рекомендації, які надавали уряди інших країн своїм освітянам) нами виокремлені такі методичні поради:

- поряд з асинхронним режимом на вча ння доцільно періодично проводити синхронне навчання, трива лість якого не повинна перевищувати 20-30 хв. Це пов'язано з психолого-фізі ологічними особливостями сприйняттяінформації. На жаль, окремі учителі цього не усвідомлюють і проводили online уроки як при традиційному навчаннітривалістю45хв.;

- доцільність використання так званої технології «перевернутого навчання». Наприклад, ми практикували на ступне: на да ва ли не обхі дну на вчальну інформаці ю учням у ка бі неті Cla ss room, якувони опра цьовува ли. Після цьо го через певний інтервал ча су організовували online конференцію з використанням сервісу Zоoтдляспільногообговорення питань заняття. B online режимі $є$ можливість доповнення матеріалу поясненням з використанням мультимедійного супроводу;

- на вчальна інформація, яка пода ється здобувача м осві ти, повинна бути структурована з домі нуваннямрізного типу схем, та блиць тощо. Доці льно пода вати інформаці ю з використа нням мультимеді йного супроводу, відеороликів, власних коротких відеоуроків;

- рекомендуємо ретельно підбиратитестові програмидля переві ркинавчальних досягнень учнів. Як свідчить досві д, використання Google форм не надає можливості реа льно які сного оці нюва ння. За ча с оцінюваннястудентимають змогу скористатись послугами Інтернет, а не лише продемонструвати власні знання. Тому доцільно використовувати тестові програми, де єобмеження ча суна виконання кожного завдання. Ми переконались, що кра щепідбиратизавдання середньої складності, що не вимагаютьтривалихв часі розрахунків, які б перевіряли знання суті теми, що вивчалася;

- для підсумкового оцінювання варто використовувати завдання творчого характеру.

\section{ВИСНОВКИ ТА ПЕРСПЕКТИВИ ПОДАЛЬШОГО ДОСЛІДЖЕННЯ}

У представленій статті наведено огляд та порівняння технічних і дидактичних можливостей хмарнихсервісів Lea rningApps, StudyStack, EDpuzzle, Ka hoot, Quizizz, які були а пробовані під час організа ціїдистанційногонавчанняунівз фізики. Вчитель на вла сний розсуд може використовува ти їх на різних ета пах за няття, зва жа ючи на поста влені освітні цілі та завдання уроку.

3 власного досвіду практичної реалізації дистанційного навчання виокремлено методичні поради щодо проведення уроків та оці нюва ння на вча льних досягнень учнів/студенті в: використання синхронного режиму на вча ння (тривалістю 20-30хв.), упровадження технології «перевернутого на вчання», структурування та ві зуа лізація на вчальної інформації, використання тестових програм перевірки рівня за своєння навча льного матеріалу, з обмеженим ча сом відповіді на запитання, та завдань творчого характеру.

Пода льшого дослідження потребує проблема організації і проведення ла бора торних робітта експериментальних досліджень у дистанційному режимі.

\section{Список використаних джерел}

1. Богачков Ю.М., Букач А.В., Ухань П.С. Комплексне застосування Google Classroom для створення варіативних дистанційних курсів. Інформаційні технології і засоби навчання. 2020. Том 76. №2. С. 290-303. URL: https://doi.org/10.33407/itlt.v76i 2.3338.

2. Головко М.В., Крижановський С.Ю., Мацюк В.М. Моделювання віртуального фізичного експерименту для систем дистанційного на вчання в за га льноосві тні й і вищі й педа гогічній школах. І нформа ційні технології і за соби навчання. 2015. Том 47. №3. С. 36-48. URL:https://doi.org/10.33407/itlt.v47i3.1224.

3. Заболотний В.Ф., Мисліцька Н.А., Слободянюк І.Ю. Хмаро орі єнтовані технології навчання: навчально-методичний посібник. Вінниця: ТОВ «ТВОРИ», 2020. 144 с.

4. Заболотний В.Ф., Слободянюк І.Ю., Мисліцька Н.А. Дида ктичні можливості використання ве б-орієнтованихтехнологій пі д ча с на вча ння фізики в кла сах гума ні та рного профі лю. І нформаційні технології і за соби на вча ння. 2018. Том65. №3. C. 53-65. URL: https://doi.org/10.33407/itlt.v65i3.2074. 
5. Куча ковська Г.А., Бодненко Д.М., Прошкін В.В. Організа ція контролю та ана лі зу успі шності студентів за кладіввищої освіти за собами соці а льних сервісів. І нформаційні технології і за соби навча ння. 2019. Том 73. №5. C. 135-148. URL: https://doi.org/10.33407/itlt.v73i5.2802.

6. Моклюк М.О. Методика використання елементів дистанційних технологій у процесі навчання фізики в за гальноосві тніх навчальних за кладах: автореф. дис. на здобуття наук. ступеня ка нд. пед. наук: 13.00.02. Київ, 2009. $22 \mathrm{c}$.

7. Організація дистанційного навчання в школі: методичні рекомендації МОН України // Упорядн.: І. Коберник, 3. Звиняцьківська. Київ, 2020. 71 с.

8. Положення про дистанційне навчання № 466 від 25 квітня 2013 року (Із змінами, внесеними згідно з Наказами Міністерства освіти і науки № 660 від 01.06.2013, № 761 від 14.07.2015): Наказ МОн № 466 від 25.04.13 року https://osvita.ua/legislation/Dist_osv/2999/

9. Теорія та практика змішаного на вчання : моногра фія / В.М. Кухаренко, С.М. Березенська, К.Л. Бугайчук, та ін;заред. В.М. Кухаренка. Харків: «Мі ськдрук», НТУ «ХПІ», 2016. 284 с.

\section{References}

1. Bohachkov, Yu.M., Bukach, A.V. \& Ukhan, P.S. (2020) Kompleksne zastosuvannia Google Classroom dlia stvorennia va ria tyvnykh dystantsiinykh kursiv [Google classroom complexapplication for creating variable distance courses]. Informatsiini tekhnolohii i zasoby navchannia - Information Technologies and Learning Tools, 76. №2. 290-303.URL: https://doi.org/10.33407/itlt.v76i2.3338 [in Ukraine].

2. Holovko, M.V., Kryzha novskyi, S.Iu. \& Matsiuk, V.M. (2015) Modeliuva nnia virtualnohofizychnohoekspenymentudlia system dystantsiinoho navchannia vzahalnoos vitnii i vys hchii peda hohichnii shkolakh [Virtual modelingofphysical experimentfor distance learning sys tems in the secondary and higher pedagogical schools].Informatsiini tekhnolohii izasobynavchanniaInformation Technologies and Learning Tools, 47. №3. 36-48. URL: https ://doi.org/10.33407/itlt.v47i3.1224 [in Ukraine].

3. Zabolotnyi, V.F., Myslitska, N.A. \& Sl obodia niuk, I.Iu. (2020). Khma ro ori ientova ni tekhnolohii navchannia [Coud-oriented technologies of training]. Vinnytsia: TOV «TVORY» [in Ukraine].

4. Zabolotnyi, V.F., Slobodianiuk, I.lu. \& Mys litska, N.A. (2018). Dyda ktychni mozhlyvos ti vykorys ta nnia veb-oriientovanykh tekhnolohii pid chas navchannia fizykyvklasakh humanitarnoho profiliu [Didactic possibilities ofthe use ofweb-based technol ogies during learning process of physics in huma nita ria n classes]. Informatsiini tekhnolohii izasobynavchannia Information Technologies and Learning Tools, 65. №3. 53-65. URL: https://doi.org/10.33407/itlt.v65i3.2074 [in Ukraine].

5. Kuchakovska, H.A., Bodnenko, D.M. \& Proshkin, V.V. (2019) Orha nizatsiia kon troliuta analizu uspishnosti studentivzakladiv vys hchoi os vity za soba my sotsia Inykh servisiv [Orga niza tion of control and a nalysis of students'achievements inhigher educational institutions bymeans of social services]. Informatsiini tekhnolohii i zasobynavchannia -Information Technologies and Learning Tools, 73. №5. 135-148. URL: https://doi.org/10.33407/itlt.v73i5.2802 [in Ukraine].

6. Mokliuk, M.O. (2009). Metodyka vykorystannia elementiv dystantsiinykh tekhnolohii u protsesi navchannia fizykyv zahal noos vitnikh navchalnykh zakla dakh [Methodol ogy of dis ta nce technol ogies elements usingin the process of physics training in the secondaryeduca tional establishments]. Extended abs tra ct of candidate's thesis. Kyiv:National Pedagogical University named after M. Dragomanov [in Ukraine].

7. Kobernyk, I. \& Zvyniatskivska, Z. (2020). Orha nizatsiia dys ta ntsiinoho na vcha nnia vshkoli:metodychni rekomendatsii MON Ukrainy [Organization of distance learning at school].Kyiv [in Ukraine].

8. Polozhennia pro dys tantsiine navchannia № 466 vid 25 kvitnia 2013 roku (Iz zmina my, vnesenymyzghidnozNakazamy Ministerstva osvity i nauky № 660 vid 01.06.2013, № 761 vid 14.07.2015): Nakaz MON № 466 vid 25.04.13 roku https://osvita.ua/legislation/Dist_osv/2999 [in Ukraine].

9. Kukha renko, V.M. etal (2016). Teoriia ta praktyka zmisha noho navchannia [Theoryand practice of blendedleaming]. «Miskdruk» [in Ukraine].

\section{USE OF CLOUD-ORIENTED TECHNOLOGIES IN THE CONDITION OF DISTANCE EDUCATION} Iryna Yu. Slobodianiuk

Mykhailo Hrushevsky Humanitarian Pedagogical College of Bar, Ukraine

Nataliia A. Myslitska, Volodymyr F. Zabolotnyi, Oksana A. Kolesnykova

Vinnytsia State Pedagogical University named after Mykhailo Kotsiubynsky, Ukraine

Abstract.

Formulation of the problem. The realities of modern times that world civilization has encountered in the wake of the pandemic have been particularlyacutein the field ofeducation. Teachers wereforced to radicallychange theforms, means, and techniquesofteaching, in a relativelyshort time. Cloud-oriented serviceshave becomesignificant technical support in the system ofdistancelearning for students. However, it is necessary to select those that are effective and most adapted to thenewformat of education, among the variety available today.

Materials and methods. Thestudy used the following main theoretical methods: analysis, systematization, and generalization ofteaching materialsand research paperson the research problem, pedagogical observationsoftheeducational processin termsofdistance learning, and testing of the proposed cloud-based services.

Results. The use ofcloud services (such as LearningApps, StudyStack, EDpuzzle, Kahoot, Quizizz) in the conditionsofdistanceeducationofstudents has been promoted a variety ofmethodsand techniquesat theorganization of explanation, actualization, and consolidation of the studied material, verification of educational achievements.

Conclusions. The analysis ofactual researcheson the introduction oftechnology of distanceeducation iscarried out. It showed that researchers prefer the asynchronousmode ofdistanceeducation. The didactic possibilities ofcloud-oriented services (namely LearningApps, StudyStack, EDpuzzle, Kahoot, Quizizz), which weretested during theorganization ofdistanceeducation in Physics, aredescribed. The comparison oftechnical and didactic possibilities of the specified cloud-oriented servicesiscarried out. Methodicaladviceon the effective organization of the educational process in the conditions of distance learning is singled out.

Keywords: distance education, cloud-oriented technologies, cloud services, LearningApps, StudyStack, EDpuzzle, Kahoot, Quizizz. 